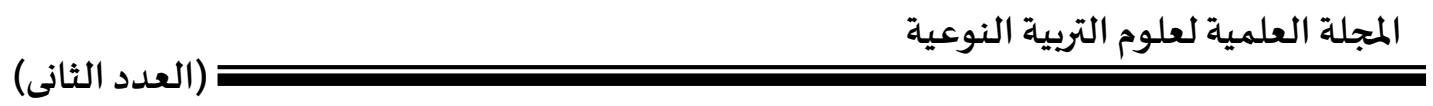

\title{
Biological and Histopathological Studies on Onions and Fenugreek in Obese Rats
}

\author{
KhaledAly Abdel RahmanShaheen ,Tarek Mohammed Abdel RahmanAfifi and \\ WafaaAlshhat Ahmed Elbermawy. \\ Department of Nutrition and Food Science, Faculty of Home Economics, Minufiya \\ University, Egypt
}

\begin{abstract}
:
The present work was conducted to study effect of different levels ( $5 \%, 10 \%$ and $15 \%$ ) fromonions and fenugreek on liver, kidney, function and blood lipid profile in rats feeding with diets containing high fat content for induction obesity. Fifty five female albino rats weighing of $250 \pm 10 \mathrm{~g}$ were used and divided into elevenequl groups, one was kept as a control-ve group, while the other groups were fed onhigh fat diet for induction obesity and treated with onions, fenugreek and mixturefrom (onions and fenugreek ) for 8 weeks. Body weight and food intake were recorded weekly. At the endof the experimental, all rats were weighted for calculation of body weight lose \%,feed efficiency ratio. Blood serum samples were used for estimation of the liver and heart functions. Serum analysis showed a significant decrease in cholesterol, triglyceride and LDL in rat groups consumed different concentrations from onions and fenugreek. While HDL was significantly increased in all rats groups comparing with control positive group, serum liver function was significantly decreased. The obtained results concluded that an improvement of all chemical analysis as compared tothe positive control group.

It can be recommended that dietary intake from onions and fenugreek to decrease the side effects ofobesity and to reach healthy conditions. Further study should be conducted to carry out the pathological and safety investigation in concern to consume onions and fenugreek for a long time.
\end{abstract}

Key words: Obese rats, fenugreek, onions, high fat,HDL,LDL,cholesterol. 


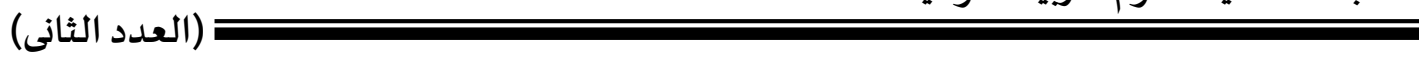

در اسات بيولوجية وتشريحية علي البصل و الحلبة في الفئران المصابة بالسمنة

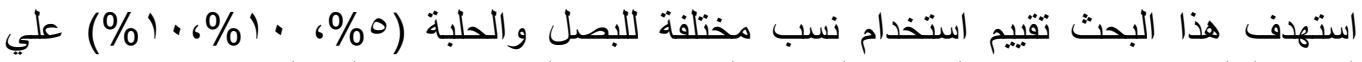

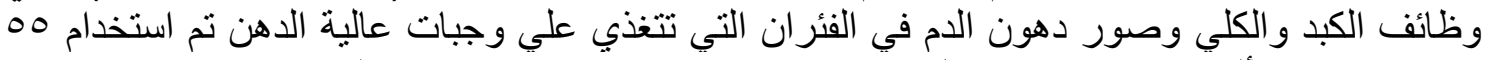

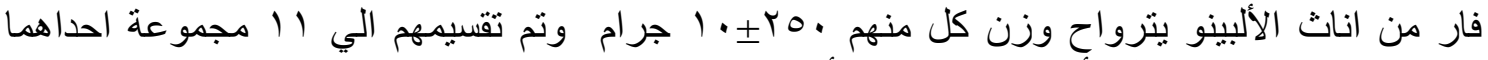

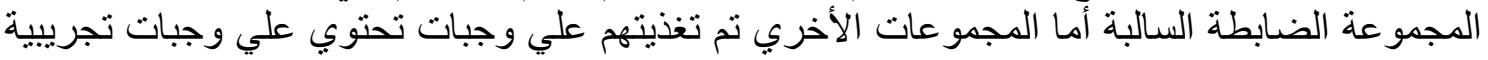

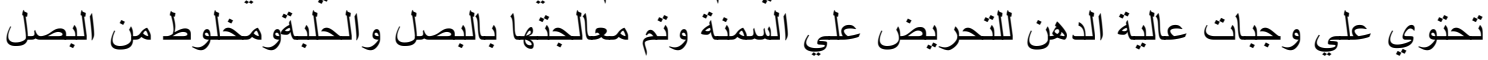

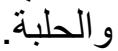

وسجل وزن الجسم والمتناول أسبو عيا وفي نهاية التجربة تم حساب معدل التغيير في وزن الجسم ومعدل

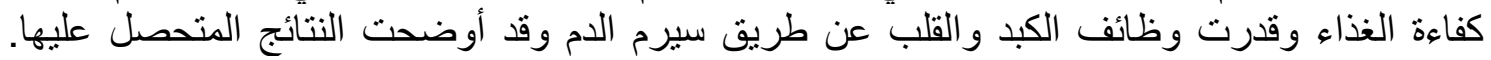

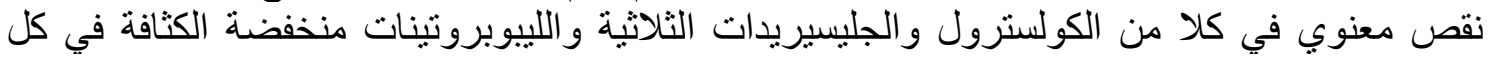

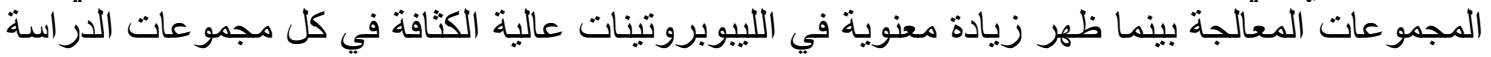
وحدوث تحسن معنوي في وظائف الكبد.

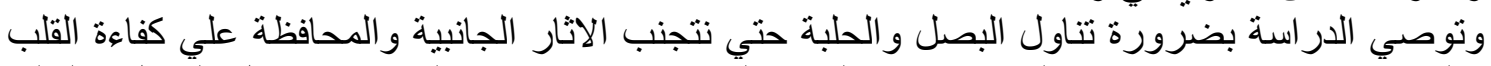

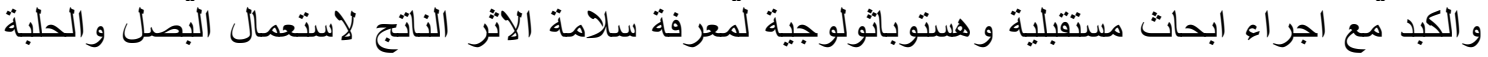

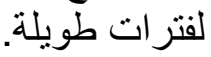

الكلمات الرئيسية: الفئران السمينة، الحلبة ، البصل،وجيات عالية الية الدهن، برتينات الدهون مرتفعة الكثافة، بروتينات الدهون منخفضة الكثافة ،الكوليسترول. 


\section{INTRODUCTION}

Rajuet al. (2001) found that the altered enzyme activities were significantly restored to control values in both the liver and kidney after Trigonella seed powder treatment. The therapeutic role of Trigonellaseed powder in type-1 diabetes as exemplified in this study can be attributed to the change of glucose and lipid metabolising enzyme activities to normal values, thus stabilizing glucose homeostasis in the liver and kidney. These biochemical effects exerted by Trigonella seeds make it a possible new therapeutic in type-1 diabetes.

Thakranet al. (2004) showed that liver degenerative and early nephropathic changes in diabetic rats. Ultrastructure of the diabetic liver revealed a reduction in the rough endoplasmic reticulum and swelling of mitochondria in the hepatocytes. TSP treatment to the diabetic rats effectively prevented the alteration in the activities of the two enzymes and partially prevented the structural abnormalities thus suggesting a protective effect of TSP on the liver and kidney of the diabetic rats. The role of TSP in reversing the diabetic state at the cellular level besides the metabolic normalization further proves its potential as an antidiabetic agent.

Arivalaganet al.(2013) found that Trigonellafoenum-graecum, commonly called fenugreek, is a leguminous plant native to many Asian, Middle Eastern and European countries. Fenugreek oil is very effective in digestion. Identification of fenugreek genotype rich in saponins and fixed oil will be useful for pharmaceutical industries. In the present study, steroidal saponin and fixed oil content was analysed in 46 diverse fenugreek genotypes on dry weight basis .

Kendler(1987) found that garlic and onion have been used for millenia in the traditional medical practice of many cultures to treat cardiovascular and other disorders. Both Allium species, their extracts, and the chemical constituents of these plants have been investigated for possible effects on cardiovascular disease risk factors--both definite (hyperlipidemia, hypertension and hyperglycemia) and suspected (platelet aggregation and blood fibrinolytic activity).

Lataet al. (1991) found that oral administration of petroleum ether extract of Allium sativum, Allium cepa and ethylacetate extract of Commiphoramukul in albino rats significantly prevented rise in serum cholesterol and serum triglyceride level, caused by atherogenic diet. All the three agents were also found to confer significant protection against atherogenic diet induced atherosclerosis.

Banqet al. (2009) indicated that onion decreased blood glucose, serum lipid levels and reduced renal oxidative stress in STZ-induced diabetic rats and this effect might exert the anti-diabetic effect of onion.

Orieet al. (2012) suggested that dietary onion extract is beneficial for improving diabetes by decreasing lipid levels. They also examined differentiation ability of rat white preadipocyte cells using the onion extract and its sulfur-containing components. Cycloalliin, S-methyl-L-cysteine, S-propyl-L- cysteine sulfoxide, dimethyl trisulfide, especially S-methyl-L- cysteine sulfoxide were reported to be 


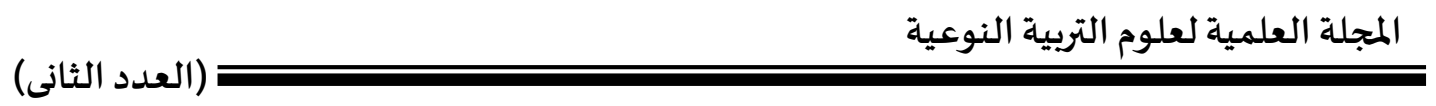

effective in inhibiting formation of oil drop in the cells, suggesting that these compounds may be involved in the anti-obesity effect of the onion extract.

Kim et al. (2013) found that the total cholesterol level, low-density lipoprotein cholesterol level and atherogenic index significantly decreased $(\mathrm{P} \leq 0.05)$. No changes were observed in activities of erythrocyte antioxidant enzymes or levels of lipid peroxidation markers following onion peel extract supplementation. Additionally, no significant difference was found in plasma antioxidant vitamin (retinol, tocopherols, carotenoids, and coenzyme Q10) levels or ex vivo H2O2provoked oxidative DNA damage after onion peel extract supplementation. The present interventional study provides evidence of the health benefits of onion peel extract and demonstrates its effects in modulating lipid profiles in healthy young Korean women.

\section{MATERIALS AND METHODS \\ Materials:}

1- Casein, all vitamins, minerals, cellulose, L- Cystine and choline chloride were obtained from El-Gomhoriya Company, Cairo, Egypt

2- Beef tallow, sucrose and corn oil were obtained from local market, Cairo,Egypt.

3- Strach was obtained from local market,Cairo,Egypt.

4- (Allium cepa )for slimming was obtained from the spices shop and Trigonellafoenum ) was obtained from the spices shop and gaind it.

\section{Animals:}

Fifty five female albino rats were obtained from The Research Institute Ophthalmology Medical Analysis Department, Giza, Egypt and divided to eleven groups of five rats,each rat housed individually in cylindncal metabolic wire cages.

-group 1 is a negative control group, 2 is a positive control and numbers from 3 to 5 were treated withTrigonellafoenum (5\% - 10\% - 15\%). Groups 6 to 8 were treated with Allium cepa (5\% - 10\% - 15\%).Groups 9 to 11 were treated with amixture of Allium cepa and Trigonellafoenum( $2.5: 2.5 \%-5: 5 \%-7.5$ $: 7.5 \%)$.

\section{Animals and Experimental Design:}

Rats housed individually inwell aerated cages under hygienic laboratory conditions,in animals house of Medical Analysis Department, Giza, Egypt.and fed for 8 weeks on high dietdiet (20\% fat and $20 \%$ protein ) for adaptation before the beginning of the experiment according toAIN (1993).

Rats were divided into 11 groups, every five rats in each group fed on certain diet for 58 days as following:

Group (1): Rats fed on normal diet as negative control.

Group (2) :Rats fed on high fat diet (20\% fat and $20 \%$ protein ) as positive control. 


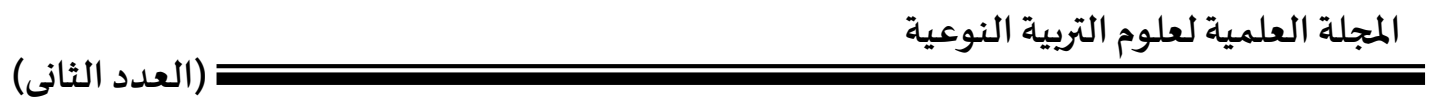

Group (3) :Obeserats fed on high fat (20\% fat and 20\% protein ) and treated with Ttrigonellafoenum (for slimming ) $5 \%$ decoction.

Group (4) : Obeserats fed on high fat (20\% fat and 20\% protein ) and treated with Ttrigonellafoenum (for slimming ) $10 \%$ decoction.

Group (5): Obeserats fed on high fat (20\% fat and 20\% protein ) and treated with Ttrigonellafoenum (for slimming ) $15 \%$ decoction.

Group (6) : Obeserats fed on high fat (20\% fat and 20\% protein ) and treated with Allium cepa(for slimming ) $5 \%$ decoction.

Group (7): Obese rats fed on high fat (20\% fat and 20\% protein ) and treated with Allium cepa(for slimming ) $10 \%$ decoction.

Group (8) : Obeserats fed on high fat (20\% fat and 20\% protein ) and treated with Allium cepa(for slimming ) $15 \%$ decoction.

Group (9) : Obese rats fed on high fat (20\% fat and 20\% protein ) and treated with amixture of Allium cepaand Ttrigonellafoenum (for slimming )2.5:2.5\% decoction.

Group (10): Obeserats fed on high fat (20\% fat and 20\% protein ) and treated with amixture of Allium cepa and Ttrigonellafoenum (for slimming ) $5: 5 \%$ decoction.

Group (11): Obeserats fed on high fat (20\% fat and 20\% protein ) and treated with amixture of Allium cepa and Trigonellafoenum (for slimming ) $7.5: 7.5 \%$ decoction.

\section{Methods:}

Food intake was calculated daily and rats were weighed weekly. Feeding and growth performance were carried out by determination of feed intake, body weight gain and feed efficiency ratio (FER) according toChapman et al. (1959), using the following formulae:

$$
\begin{array}{ll}
\text { FER }= & \frac{\text { Body weight gain }(\mathrm{g})}{\text { Feed Intake }(\mathrm{g})} \\
(\mathrm{BWG} \%)= & \frac{\text { Final weight }- \text { Initial weight }}{\text { Initial weight }} \times 100
\end{array}
$$

At the end of the of the experiment period(8weeks), rats were starvedfor $12 \mathrm{hr}$., then sacrificed under ether for anesthesia. Blood samples were collected into clean dry centrifuge tubes and stored at room temperature for 15 minutes, then put into a refrigerator for 2 hour; after that centrifuged for 10 minutes at $3000 \mathrm{rpm}$ to separatetransferred into dry clean Wasserman tubes using a Pasteur pipette and then kept frozen at $\left(-20 \mathrm{C}^{\circ}\right)$ till analysis.

\section{Biochemical Analysis:}

Serum total cholesterol was calorimetrically determined according to Allainet al. (1974) and triglyceride was determined calorimetrically according to Wahlefeld (1974). High Density Lipoprotein cholesterol (HDL-c) was determined calorimetrically according to Richmond (1973). Low Density Lipoprotein 
cholesterol (LDL-c) and Very Low Density Lipoprotein cholesterol (VLDL-c) were calculated mathematically according to Friedewaldet al. (1972):LDL-c = TC-[HDL-c + (TG/5)] VLDL-c = Triglycerides/5.

Serum glucose and serum insulin were estimated according toTrinder (1969). Serum Asparate and Alanine amino transferases (AST and ALT) were determined using enzymatic colorimetric methodsYoung(1990) andTietz (1976). Statistical Analysis:

Statistical analysis was performed using computer program, Statistical Package for Social science and compared with each other using the suitable testsSPSS(1998).

\section{RESULTS AND DISCUSSION}

Data present in Table(1) show effect of feeding with different concentrations $(5 \%, 15 \%$ and $15 \%$ ) foronions, fenugreek and their mixture of them on food intake, body weight gain $\%$ and feed efficiency ratio in obeserats.

The mean value of feed intake of control positive group was $18.72 \mathrm{gwhile}$ the mean value of control negative group was $16.86 \mathrm{~g}$. The obtained results showed that there were non- significant differences expect for 5\%,10\% and $15 \%$ tested groups as compared to positive groups.

The same table showed the highest mean value of BWG\% was 95.62 for rats fed on control positive group. While the lowest mean value was $15.45 \mathrm{~g}$ and $25.72 \mathrm{~g}$ of rats fed on diet containing for $15 \%$ mixture of onions and fenugreek and $15 \%$ for fenugreek. However, feeding rats on 5\% onions and onions $10 \%$ gave the highest values as compared with the other treatments.

There were a significant decrease in BWG\% among all tested groups as compared to positive group.

As for FER, the results show that mean value of all groups were a significantly differences among all tested groups as compared to positive groups expect for rats feeding 5\% Which was significant $(\mathrm{P} \leq 0.05)$.

The mean values of feed intake were almost the same in most of cases, food efficiency ratio showed a pronounced decrease as compared to the negative control. This reduction may be due to the decrease of body weight during the experimental period.

The results agreed withGisele et al . ( 2011)andParveenand Uma(2013)reported that onions and fenugreek supplemented can decrease the body weight gain than that of control group but the difference was not significant.

Parveenet al .(2013)found that results were comparable with orlistat, a anti obesity drug, and standard provide clear evidence that the AqE-TFG treatment offered significant protection against MSG-induced dyslipidemia and oxidative stress.

Vatset al.(2004) found that administration of all the three plant extracts exerted a favorable effect on body weight and blood glucose. 
Gisele et al.( 2011) found that NAC improved high- sucrose diet-induced obesity and its effects on glucose tolerance, lipid profile, in vivo LDL-oxidant defences.

Table (1): Feed intake (F1) g, body weight gain (BWG\%) and feed efficiency ratio (FER) of control and obese rats treated withonions, fenugreek. and mixture from them .

\begin{tabular}{|l|l|l|l||}
\hline $\begin{array}{l}\text { fparameters } \\
\text { Grops }\end{array}$ & $\begin{array}{l}\text { Feed intake } \\
\text { g/day }\end{array}$ & BWG \% & FER \\
\hline \hline Negative group & $18.72 \pm 7.35$ & $40.85 \pm 3.15$ & $2.182 \pm 0.081$ \\
\hline Positive group & $16.86 \pm 2.38$ & $95.62 \pm 1.38$ & $5.671 \pm 0.39$ \\
\hline Fenugreek 5\% & $16.08 \pm 1.75$ & $53.83 \pm 1.13^{* *}$ & $3.347 \pm 0.014$ \\
\hline Fenugreek 10\% & $16.71 \pm 1.61$ & $42.5 \pm 2.04^{* *}$ & $2.543 \pm 0.026$ \\
\hline Fenugreek 15\% & $15.65 \pm 1.54$ & $25.72 \pm 1.62^{* * *}$ & $1.643 \pm 0.091$ \\
\hline Onions 5\% & $16.91 \pm 3.23$ & $68.81 \pm 3.28^{*}$ & $4.069 \pm 0.251$ \\
\hline Onions 10\% & $16.42 \pm 3.19$ & $58.59 \pm 2.16^{* *}$ & $3.568 \pm 0.136$ \\
\hline Onions 15\% & $15.82 \pm 3.52$ & $35.76 \pm 1.54^{* * *}$ & $2.260 \pm 0.101$ \\
\hline Mixture2.5:2.5\% & $16.18 \pm 2.16$ & $46.69 \pm 1.46^{* *}$ & $2.885 \pm 0.026$ \\
\hline Mixture 5:5\% & $16.32 \pm 1.81$ & $40.95 \pm 1.16^{* *}$ & $2.509 \pm 0.031$ \\
\hline Mixture7.5:7.5\% & $16.38 \pm 1.19$ & $15.45 \pm 1.31^{* * *}$ & $.0943 \pm 0.061$ \\
\hline
\end{tabular}

Mixture : (onions and fenugreek ).

*Differences are significant at $\mathrm{P} \leq 0.05 \quad * *$ Differences are highly significant at $\mathrm{P} \leq 0.01$

$* * *$ Differences are highly significant at $\mathrm{P} \leq 0.001$.

\section{Feed efficiency ratio}

Table (2) illustrate the festing serum lipids and the effect of feeding with different concentrations $(5 \%, 10 \%$ and $15 \%$ )foronions, fenugreek and mixture from them on serum lipids of obese rats.

It could be observed that total cholesterol, TG and LDL decreased as a result of adding onions,fenugreek and mixture from them in the diet. There were very highly significant difference in TC and TG of mixture from onions and fenugreek $15 \%$ group as compared to positive group. As for HDL, the.mean value of negative control was higher than that of positive control. While the mean values of groups fed on diets with $15 \%$ mixture for onions and fenugreek and $15 \%$ onions were more significantly higher than that of positive control.

Concerning LDL, the mean value of negative control was lower than that of positive control. The mean values of all the groups were significantly lower than that of positive control. 
The results agreed with Kim et al. (2013) and Atta et al. (2012) they showed that,onions and fenugreek decreased total cholesterol,LDL cholesterol and triglycerides .

Parveen and $U m a(2013)$ found that AqE-TFG (Aqueous extract of Trigoellafoenumgarecum) produced significant reduction in serum total cholesterol (TC), triglycerides (TGs), lactate dehydrogenase (LDH) and elevationin serum high density lipoprotein cholesterol (HDL-C), hepaticand cardiac antioxidant enzymes

Kim et al.(2013) found that the total cholesterol level, low-density lipoprotein cholesterol level and atherogenic index significantly decreased $(\mathrm{P} \leq 0.05)$.

Table (2):Mean values of lipids parameters of control and obese rates treated fed on

onions,fenugreek and mixture from them.

\begin{tabular}{|l|l|l|l|l|l|}
\hline Serum lipids & $\begin{array}{l}\text { Total } \\
\text { cholesterol }\end{array}$ & Triglycerides & HDL-cholesterol & LDL-cholesterol & VLDL-cholesterol \\
\hline \hline Negative group & $168.13 \pm 5.06$ & $70.85 \pm 3.27$ & $54.91 \pm 1.17$ & $99.05 \pm 2.32$ & $14.17 \pm 0.73$ \\
\hline Positive group & $196.87 \pm 2.31$ & $93.73 \pm 2.15$ & $43.48 \pm 0.92$ & $134.65 \pm 4.15$ & $18.74 \pm 0.56$ \\
\hline Fenugreek 5\% & $188.33 \pm 3.19$ & $88.61 \pm 1.37$ & $47.16 \pm 0.76^{*}$ & $123.45 \pm 4.50$ & $17.72 \pm 0.89$ \\
\hline Fenugreek 10\% & $180.02 \pm 2.57^{*}$ & $82.45 \pm 1.16^{*}$ & $50.53 \pm 2.31^{*}$ & $113.0 \pm 2.46^{*}$ & $16.49 \pm 0.92$ \\
\hline Fenugreek 15\% & $178.15 \pm 1.88^{* *}$ & $77.55 \pm 1.33^{* *}$ & $51.07 \pm 1.19^{* *}$ & $111.57 \pm 1.88^{*}$ & $15.51 \pm 0.64^{*}$ \\
\hline Onions 5\% & $186.19 \pm 1.51$ & $85.47 \pm 1.11$ & $50.38 \pm 1.38^{*}$ & $118.72 \pm 1.93^{*}$ & $17.09 \pm 0.79$ \\
\hline Onions 10\% & $178.46 \pm 1.67^{* *}$ & $79.75 \pm 2.47^{* *}$ & $51.01 \pm 2.15^{* *}$ & $111.50 \pm 0.65^{*}$ & $15.95 \pm 0.25^{*}$ \\
\hline Onions 15\% & $175.77 \pm 6.13^{* *}$ & $76.81 \pm 3.81^{* *}$ & $53.46 \pm 3.08^{* * *}$ & $106.95 \pm 2.29^{* *}$ & $15.36 \pm 0.67^{* * *}$ \\
\hline Mixture2.5:2.5\% & $180.48 \pm 2.31$ & $80.17 \pm 2.97^{*}$ & $50.78 \pm 1.27^{* *}$ & $113.67 \pm 2.28$ & $16.03 \pm .044$ \\
\hline Mixture 5:5\% & $177.67 \pm 5.43^{* *}$ & $75.31 \pm 1.81^{* *}$ & $50.29 \pm 3.11^{* *}$ & $111.69 \pm 4.67^{* *}$ & $15.06 \pm 0.27^{* * *}$ \\
\hline Mixture7.5:7.5\% & $173.23 \pm 3.11^{* *}$ & $73.28 \pm 1.05^{* *}$ & $53.87 \pm 1.32^{* * *}$ & $104.71 \pm 1.63^{* *}$ & $14.65 \pm 0.66^{* * *}$ \\
\hline
\end{tabular}

Mixture : (onions and fenugreek).

*Differences are significant at $\mathrm{P} \leq 0.05 \quad * *$ Differences are highly significant at $\mathrm{P} \leq 0.01 \quad * * *$ Differences are highly significant at $\mathrm{P} \leq 0.001$.

Table (3) showsserum ALT, AST and serum glucose of control positive and different groups of obese rats fed on different concentration $(5 \%, 10 \%$ and $15 \%)$ from onions, fenugreek and mixture from them. It's clear that ALT and AST for control positive was higher than control negative.

It could be observed the improvement of ALT and AST was highest for mixture

Fenugreek $5 \%$ from onions and fenugreek 15\% diet ( 6.20 and 16.11 ) while was lowest for diet (7.11 and 19.76) difference were high significant $(\mathrm{P} \leq 0.001)$ when compared with control positive group. 


\section{(العدد الثانى)}

This result in table (3) agreed with those reported by Parveen and Uma(2013) aspartate amino transferase (AST), alanine amino transferase (ALT), hepatic and cardiac lipid peroxides (MDA) levels.

Mete et al . (2013) indicated that pretreatment with ACE (Allium cepa) protects against DOX- (Doxorubicin) induced hepatotoxicity due to the antioxidant properties of ACE. Further studies on efficacy of antioxidant treatment by ACE in DOX-mediated toxicity and underlying mechanisms would provide a better explanation.

Table (3):Mean values of liver functionparameters of control and obese rates treated fed on onions, fenugreek and mixture from them.

\begin{tabular}{|l|l|l|}
\hline \hline Grops parameters & ALT u/l & AST u/l \\
\hline \hline Negative group & $6.17 \pm 0.13$ & $16.25 \pm 0.091$ \\
\hline Positive group & $7.71 \pm 0.36$ & $20.67 \pm 0.53$ \\
\hline Fenugreek 5\% & $7.11 \pm 0.011$ & $19.76 \pm .075$ \\
\hline Fenugreek 10\% & $6.53 \pm 0.049^{*}$ & $19.33 \pm 1.10$ \\
\hline Fenugreek 15\% & $6.37 \pm 0.021^{* *}$ & $17.63 \pm .073$ \\
\hline Onions 5\% & $6.65 \pm 0.033$ & $18.46 \pm 0.90$ \\
\hline Onions 10\% & $6.43 \pm 0.018^{* *}$ & $17.15 \pm 0.54^{*}$ \\
\hline Onions 15\% & $6.31 \pm 0.011^{* *}$ & $16.32 \pm 0.18^{* *}$ \\
\hline Mixture 2.5:2.5\% & $6.38 \pm 0.218^{* *}$ & $17.17 \pm 0.26^{*}$ \\
\hline Mixture 5:5\% & $6.33 \pm 0.027^{* *}$ & $16.56 \pm 0.88^{* *}$ \\
\hline Mixture 7.5:7.5\% & $6.20 \pm 0.015^{* * *}$ & $16.11 \pm 0.37^{* *}$ \\
\hline
\end{tabular}

Mixture : (onions and fenugreek ).

$*$ Differences are significant at $\mathrm{P} \leq 0.05 \quad * *$ Differences are highly significant at $\mathrm{P} \leq 0.01$ $* * *$ Differences are highly significant at $\mathrm{P} \leq 0.001$.

Table (4) showsserum glucose of control positive and different groups of obese rats fed on different concentration $(5 \%, 10 \%$ and $15 \%$ ) of onions, fenugreek and mixture from them It's clear that serum glucose of control positive was higher than control negative.

It could be observedthe improvement of serum glucose was highest for $15 \%$ diet mixture of onions and fenugreek $(79.63 \mathrm{mg} / \mathrm{dl})$ while it was lowest for fenugreek

$5 \%$ diet $(81.75 \mathrm{mg} / \mathrm{dl})$, the difference was high significant $(\mathrm{P} \leq 0.01)$ when comparedwith control positive group. 
(العدد الثانى)

This result agreed with those reported by Tripathiand Chandra (2009)

That extractsin diabetic rats has remarkably improved the elevated levels of lipid fasting blood glucose. A significant decreasein peroxidation $(p \leq 0.001)$ significant.

Imadet al . 2010 ) found that in assessment of hypoglycaemic activity of Allium cepa in type 1 and type 2 diabeticpatients, ingestion of crudeAllium cepa $(100 \mathrm{~g})$ caused a considerable reduction in fasting blood glucoselevels by about 89

$\mathrm{mg} / \mathrm{dl}$ in relation to insulin $(145 \mathrm{mg} / \mathrm{dl})$ in type 1 diabetic patients and it reduced fasting blood glucose levels by $40 \mathrm{mg} / \mathrm{dl}$.

Table (4): Mean values of serum glucose parameters of control and obese rates treated fed on onions, fenugreek and mixture from them.

\begin{tabular}{|c|c|}
\hline $\begin{array}{ll}\text { Grops } & \text { parameters }\end{array}$ & Serum Glucose mg/dl \\
\hline Negative group & $75.17 \pm 3.38$ \\
\hline Positive group & $94.22 \pm 6.18$ \\
\hline Fenugreek $5 \%$ & $89.93 \pm 1.19$ \\
\hline Fenugreek $10 \%$ & $86.32 \pm 2.65$ \\
\hline Fenugreek $15 \%$ & $84.97 \pm 1.11$ \\
\hline Onions & $85.36 \pm 2.06$ \\
\hline Onions & $84.22 \pm 1.87$ \\
\hline Onions & $81.75 \pm 2.34^{*}$ \\
\hline Mixture $2.5: 2.5 \%$ & $83.27 \pm 3.63$ \\
\hline Mixture & $82.81 \pm 5.16^{*}$ \\
\hline Mixture $7.5: 7.5 \%$ & $79.63 \pm 4.82^{* *}$ \\
\hline
\end{tabular}

Mixture : (onions and fenugreek ).

*Differences are significant at $\mathrm{P} \leq 0.05 \quad * *$ Differences are highly significant at $\mathrm{P} \leq 0.01 \quad * * *$ Differences are highly significant at $\mathrm{P} \leq 0.001$. 1 Feed efficiency ratio 


\section{REFERENCES}

AIN. (1993).American Institute of Nutrition Purified Diet for Laboratory Rodent ,Final Report. J.Nutrition, 123:1939-1951.

Allain, C. C.; Poon, L. S. and Chan, C. S. (1974). Enzymatic determination of serum total cholesterol. Clin. Chem., 20: 470-475.

Arivalagan,M.; Gangopadhyay, .K. K.and Kumar.G.(2013).Determination of steroidal saponins and fixed oil content in fenugreek (Trigonellafoenumgraecum) fenotypes.indian J Pharm, 75(1): 110-113.

Atta, E.; A, Balgess.and John, M.(2012). Effect of fenugreek

(Trigonellafoenmgreacum )seed dietary levels on lipid profile and body weight gain of rats. Pakistan Journal of Nutrition, 11 (11) : 1004- 1008.

Banq, M. A.; Kim, H. A. and Cho, Y. J.(2009).Alterations in the blood glucose, serum lipids and renal oxidative stress in diabetic rats by supplementation of onion (Allium cepa.Linn).Nutr Res Pract, 3(3):242-246.

Champan, D. C.; Castilla, R. and Campbell J. A. (1959). Evaluation of protein in food: A Method for thedetermination of protein efficiency ratio. Can. J. Biochem. Physiol., 37:679-688.

Friedewald, W. T.; Levy, R. I. and Friedrickson, D. S. (1972). Estimation of plasma or erum low density lipoprotein cholesterol concentration without use ofpreparaline ultracentrifuge. Clin. Chem., 18: 499-502.

Gisele, A. S.; Geovana, X. E .and Ethel, L. B. N. (2011). N-Acetylcysteine an alliumplant compound improves high-sucrose diet-induced obesity and related effects. Published online.

Imad, M. T. E.; Elhadi, M. . and AbdElwahab, H. M.(2010).Preliminary study of the clinical hypoglycemic effects of Allium cepa (Red Onion) in Type 1 and Type 2 Diabetic Patients. Environ Health Insights, 4: 71-77.

Kendler, B. S. (1987). Garlic (Allium sativum) and onion (Allium cepa): a review of their relationship to cardiovascular disease. Prev Med, 16(5):670685.

Kim, J.; Cha, Y. J.; Lee, K. H.and Park, E.(2013).Effect of onion peel extract supplementation on the lipid profile and antioxidative status of healthy young women: a randomized, placebo-controlled, double-blind, crossover trial. Nutr Res Pract, 7(5):373-379.

Kim, J.; Cha, Y. J.; Lee, K. H.and Park, E.(2013): Effect of onion peel extract supplementation on the lipid profile and antioxidative status of healthy young women: a randomized, placebo-controlled, double-blind, crossover trial. Nutr Res Pract, 7(5):373-379

Lata, S.; Saxena, K. K.; Bhasin, V.; Saxena, R.S.; Kumar, A. and Srivastava, V. K.(1991). Beneficial effects of Allium sativum, Allium cepa and Commiphoramukul on experimental hyperlipidemia and atherosclerosis--a comparative evaluation.Open access journal indexed with Index Medicus\& ISI's SCI,37(3): 132-135. 
(العدد الثانى)

Mete, R.; Oran, M.; Topcu, B.; Oznur, M.; Seber, E. S.; Gedikbasi, A,. and Yetisyigit, T. (2013). Protective effects of onion (Allium cepa) extract against doxorubicin-induced hepatotoxicity in rats.ToxicolInd Health.

Orie, Y.; Yoshiaki, S. and Kiharu, I. (2012). Anti-obesity effects of onion extract in zucker diabetic fatty rats. Nutrients, 4(10): 1518-1526.

Parveen, K .and Uma, B.(2013).Protective effect of Trigonellafoenumgraecum Linn. on monosodium glutamate-induced dyslipidemia and oxidative stress in rats. Indian J Pharmacol, 45(2): 136-140.

Raju, J.; Gupta, D.; Rao, A.R.; Yadava, P.K.and Baquer, N. Z.(2001).Trigonellafoenumgraecum (fenugreek) seed powder improves glucose homeostasis in alloxan diabetic rat tissues by reversing the altered glycolytic, gluconeogenic and lipogenic enzymes. Mol Cell Biochem, 224(1-2):45-51.

Richmond, N. (1973). Colorimetric determination of total cholesterol and highdensity lipoprotein cholesterol (HDL-c). Clin. Chem., 19: 1350-1356.

SPSS (1998). Statistical Package for social science and Computer Software,Ver. 10., SPSS Company London, UK.

Thakran, S.; Siddiqui, M. R. andBaquer, N. Z. (2004).Trigonellafoenumgraecum seed powder protects against histopathological abnormalities in tissues of diabetic rats. Mol Cell Biochem, 266(1-2):151-159.

Tietz, N. W. (1976).Fundmental of Clinical Chemistry Philadelphia, W.B. Sanuder, P. 243.

Trinder.P. (1969).Determination of glucose in blood using glucose ox-idase with an alternative oxygen acceptor. Ann. Clin. Biochem.;6-24.

Tripathi, U. N. andChandra, D. (2009). The plant extracts of Momordicacharantia and Trigonellafoenum-graecum have anti-oxidant and anti-hyperglycemic properties for cardiac tissue during diabetes mellitus. Oxid Med Cell Longev, 2(5):290-296.

Vats, V.; Yadav, S. P.; Biswas, N. R.andGrover, J. K. (2004). Anti-cataract activity of Pterocarpusmarsupium bark and Trigonellafoenum-graecum seeds extract in alloxan diabetic rats. J Ethnopharmacol, 93(2-3):289-294.

Wahlefeld, A. W. (1974). Methods of Enzymatic Analysis, Academic Press, Chapter 5,pp: 1831-1835.

Young, D. S. (1990): Effects of Drugs on Clinical Laboratory Tests. Third edition, 3:2-12. 